\title{
Stem Cell Therapy: A Promising Therapeutic Approach for Multiple Sclerosis
}

FERESHTEH POURABDOLHOSSEIN ${ }^{1,2}$ • HATEF GHASEMI HAMIDABADI ${ }^{3,4} \bullet$ MARYAM NAZM BOJNORDI ${ }^{3,4} \bullet$ SINA MOJAVERROSTAMI ${ }^{5}$

${ }^{1}$ Cellular and Molecular Biology Research Center, Health Research Institute, Babol University of Medical Sciences, Babol, Iran; ${ }^{2}$ Physiology Departments, Faculty of Medicine, Babol University of Medical Sciences, Babol, Iran; ${ }^{3}$ Department of Anatomy \& Cell Biology, Faculty of Medicine, Mazandaran University of Medical Sciences, Sari, Iran; ${ }^{4}$ Immunogenetic Research Center, Faculty of Medicine, Mazandaran University of Medical Sciences, Sari, Iran; ${ }^{5}$ Department of Anatomy, School of Medicine, Tehran University of Medical Sciences, Tehran, Iran

Author for correspondence: Maryam Nazm Bojnordi, Immunogenetic Research Center, Department of Anatomy \& Cell Biology, Faculty of Medicine, Mazandaran University of Medical Sciences, Sari, Iran. E-mail: bojnordi@modares.ac.ir

Doi: http://dx.doi.org/10.15586/codon.multiplesclerosis.2017.ch6

Abstract: Multiple sclerosis (MS) is an inflammatory disease of the central nervous system which is accompanied by demyelination of the nerves, axonal loss, and disability. Currently, no definitive treatment is recognized for MS. Stem-cell therapy for MS has shown promising results and has attracted attention as an alternative therapeutic option. Various stem cell sources such as mesenchymal, embryonic, and neural have been identified. This chapter gives an overview of the advances made in our understanding of these stem cells under two broad categories: exogenous and endogenous. Stem-cell therapy in MS and the substantial literature regarding their

In: Multiple Sclerosis: Perspectives in Treatment and Pathogenesis. Ian S. Zagon and Patricia J. McLaughlin (Editors), Codon Publications, Brisbane, Australia. ISBN: 978-0-9944381-3-3; Doi: http://dx.doi.org/10.15586/codon.multiplesclerosis.2017

Copyright: The Authors.

Licence: This open access article is licenced under Creative Commons Attribution 4.0 International (CC BY-NC 4.0). https://creativecommons.org/licenses/by-nc/4.0/ 
therapeutic potential for MS are discussed. Much of the promising data are still in experimental stage, and further clinical trials are needed to rigorously evaluate the safety, validity, and feasibility of these stem cells for the treatment of MS.

Key words: Endogenous stem cells; Mesenchymal stem cells; Multiple sclerosis; Pluripotent stem cells; Stem-cell therapy.

\section{Introduction}

Multiple sclerosis (MS) is an autoimmune disease that affects the central nervous system (CNS) and leads to demyelination of neural fibers, severe neurological symptoms, and progressive disability $(1,2)$. None of the currently available drugs are effective in supporting regeneration of the demyelinated areas, and preventing disease progression (2). Stem cells, because of their self-renewal and differentiation capacity into various cell types, appear to be suitable candidates for alternative therapeutic strategies for MS $(3,4)$. A wide variety of stem cells that have therapeutic potential in neurodegenerative diseases have been identified; these include, but are not limited to, mesenchymal stem cells (MSCs), embryonic stem cells (ESCs), and neural stem cells (NSCs) (3-5).This chapter gives an overview of stem cells and their therapeutic potential for MS.

\section{Exogenous Stem Cell Therapy in MS}

\section{BONE MARROW MESENCHYMAL STEM CELLS}

Bone marrow mesenchymal stem cells (BMSCs) are multipotent stem cells that are derived from the bone marrow and have chondrogenic, osteogenic, and adipogenic differentiation capacities. They can also differentiate into neurons and glial cells $(6,7)$. The anti-inflammatory, low immunogenicity, and multipotency characteristics of BMSCs render them as a desirable cell source in regenerative medicine $(6,7)$. Unlike other source of stem cells, ethical concerns or tumorigenic activity is not a concern with BMSCs. They can be cultured and propagated easily in vitro, and autologous transplantation can be achieved without rejection $(8,9)$. BMSCs exhibit migration and homing ability into damaged parts of CNS. Transplantation of this cell population into damaged neural tissues leads to functional improvement via formation of glia and neurons that is identifiable at molecular and cellular levels (10-12). Furthermore, BMSCs have the ability to secrete many autocrine and/or paracrine factors that prevent apoptosis, and mediate neurogenesis and angiogenesis $(13,14)$. These neurotrophic and neuroprotective factors increase viability and proliferation of neuroglial cells and promote repair and recovery $(15,16)$. Several studies have confirmed the capacity of BMSCs to improve remyelination following experimental autoimmune encephalomyelitis (EAE) $(17,18)$. These results suggest that BMSCs are promising cell sources for functional recovery in MS patients. Auto transplantation of BMSCs in patients leads to significant recovery, and limits disability $(19,20)$. 
The transplantation of differentiated BMSCs results in better glial cell engraftment than undifferentiated BMSCs. Transplantation of neuroglial progenitors derived from BMSCs enhances the homing and functional maturation rate of the cells $(21,22)$. Although the mechanisms that control neuroglial differentiation of BMSCs are not clearly understood, they can be differentiated into neuroglial phenotypes using growth factors, retinoic acid, and cytokines $(23,24)$. Recovery of the demyelinated areas and promotion of remyelination following transplantation of glial progenitors derived from BMSCs in animal MS models have been documented $(25,26)$. In experimental animal models, BMSCs have been shown to reduce immune attack to myelin sheets by suppressing T-lymphocyte proliferation $(27,28)$, diminishing inflammation and demyelination, inducing oligodendrogenesis (12), and improving remyelination (29) and tissue regeneration (10). Clinical trials suggest that BMSCs have the potential to reduce infiltration, decrease demyelinated areas, and improve axonal formation and functional recovery (30).

\section{HEMATOPOIETIC STEM CELLS}

Hematopoietic stem cells are isolated from bone marrow and give rise to hematopoietic and lymphopoietic precursor cells, and lymphoid to myeloid lineage cells. Cell-therapy strategies based on engraftment of hematopoietic stem cells have been shown to result in neurological regeneration and repopulation of the immune system (31-35). In animal models, similar positive effects have been reported; however, controversial results also exist $(36,37)$. Engraftment of hematopoietic stem cells causes clinical improvement in MS patients $(38,39)$, and auto transplantation of hematopoietic stem cells show positive results in the management of progressive MS $(40,41)$. Some systematic reviews show that hematopoietic stemcell therapy in patients with progressive MS leads to recovery of neurological function and prevents mortality of patients (42-45).

\section{UMBILICAL CORD MSCS}

Several studies have shown the therapeutic potential of human umbilical cordderived mesenchymal stem cells (hUC-MSC) in MS patients. hUC-MSCs are promising candidate sources of MSCs that can be collected without pain. They have a faster self-renewal ability compared to other MSCs (46), and they differentiate into a variety of cell types such as bone, cartilage, adipose, muscle, cardiomyocyte, neuron, astrocyte, and oligodendrocyte (47). There is compelling evidence that hUC-MSCs, compared to BM-MSCs, have higher proliferation and differentiation abilities, and stronger immune tolerance because of lower human leukocyte antigen-1 (HLA-1) expression (48, 49). hUC-MSCs can improve clinical manifestations in the animal model of EAE. hUC-MSC-treated EAE mice showed long-term (50 days) recovery of behavioral functions and improvement of histopathological characteristics, including suppression of perivascular immune cell infiltrations and reduction of demyelination in the spinal cord (50). The first report of successful treatment of an MS patient with hUC-MSC was published in 2009 (51). After transplantation of hUC-MSC in a patient with refractory progressive MS, the disease course was stabilized with signs of improved sensory function 
and muscle strength, and the patient could even stagger along with the help of family (51). In subsequent clinical experiments, during a l-year observation period, no significant adverse effects were found in groups treated with hUCMSC, indicating a better safety profile of these stem cells (52). Administration of hUC-MSC showed lower relapse occurrence and EDSS (Expanded Disability Status Scale) scores in MS patients. Assessment of inflammatory cytokines demonstrated a shift from Th1 to Th2 immunity in treated patients. An increase in HGF was also observed in hUC-MSC-treated group which may have played a role in the improvement of MS. HGF is a multifunctional cytokine which is important for tissue regeneration with its ability to stimulate mitogenesis, cell motility, and matrix invasion (52). According to a case report, a 25-year-old MS patient, throughout the 4-year treatment period (2008-2012) with BM and UC-MSC, was completely free of clinical and radiological disease activity. Also, the patient had good recovery from severe relapse and was able to walk unaided. No new lesions were observed on the MRI performed at the end of the treatment period, and many lesions had resolved (53).

\section{HUMAN WHARTON'S JELLY MSCS}

Wharton's jelly is a mucoid connective tissue that surrounds the umbilical vessels. Human Wharton's jelly-derived mesenchymal stem cells (hWJ-MSCs) are a valuable alternative to BM-derived stem cells (54). They can differentiate into many different cell types, including fat, bone, cartilage, and neural cells (29, 55-58). In an experimental model of EAE, transplantation of hWJ-MSCs-derived oligodendrocyte progenitor cells into the brain ventricles of mice reduced the clinical signs of EAE and significantly increased remyelination (59). In another study on rat EAE model, hWJ-MSC suppressed proliferation of activated T-cells with contactdependent and paracrine mechanisms. Indoleamine 2,3-dioxygenase 1 was shown as the major effector molecule responsible for T-cell suppression (60).

\section{ADIPOSE-DERIVED MSCS}

Adipose tissue is an abundant and accessible source of MSCs that can be obtained easily in sufficient quantities with a minimal invasive procedure. These adiposederived mesenchymal stem cells (AdMSCs) are multipotent and differentiate into chondrocyte, myocyte, neuronal, and osteoblast lineages $(61,62)$, and are effective in the treatment of immune-related diseases, including GVHD, MS, and rheumatic disease (63). The differentiation and immunomodulatory potencies of AdMSCs are equivalent to that of BMSCs. Whereas hAdMSC derived from elderly and young donors showed similar proliferation, differentiation, and senescence marker patterns, BMSCs from the elderly showed reduced proliferation, decreased differentiation, and increased senescence (64). The therapeutic potential of AdMSCs in a mouse model of peripheral nerve sciatic crush has been demonstrated (65). The therapeutic efficacy of AdMSCs isolated from lean and obese persons indicated that obesity reduces the anti-inflammatory effects of human AdMSCs such that they may not be a suitable cell source for the treatment of autoimmune diseases (66). AdMSCs are a valuable source of adult MSC with neuronal differentiation ability, and are a useful remedy to treat neurodegenerative diseases (67). 
Recent studies suggest that AdMSCs have a significant beneficial effect on chronic EAE model, both in the preclinical phase of the disease and after the disease has entered an irreversible clinical course (68). In EAE lesions, the amelioration of clinical scores was accompanied by a strong reduction of spinal cord inflammation as well as demyelination and axonal damage. Administration of AdMSCs in chronic EAE induces a Th2-type cytokine shift in T-cells. The penetration of AdMSCs within demyelinated areas is accompanied by increased number of endogenous oligodendrocyte progenitors (69). Additional studies showed that murine AdMSCs (mASCs) suppress T-cell proliferation via inducible nitric oxide synthase (iNOS) and cyclooxygenase (COX-2) activities. mASCs also prevented lipopolysaccharide (LPS)-induced maturation of dendritic cells (DCs) (70). The efficacy of intravenous AdMSCs transplantation in remyelination, in mouse cuprizone model of MS, can be significantly enhanced by $17 \beta$-estradiol (E2) administration (71). AdMSCs can upregulate immunomodulatory cytokines, such as TGF- $\beta$, and downregulate inflammatory cytokines, such as IFN- $\gamma$, and transcription factors, such as t-bet (72). Brains and lymph nodes of EAE rats treated with AdMSCs show a significant expression of human leukocyte antigen $G(H L A-G)$ gene. The immunomodulatory effects of AdMSCs may be related to their secretion of HLA-G (73). Engineering of AdMSCs as carriers for IFN- $\beta$ delivery, or secretors of IL-10, has shown beneficial effects in experimental models of MS $(74,75)$.

\section{NEURAL STEM CELLS}

NSCs are unipotent stem cells found in the subventricular zone (SVZ) of the lateral ventricle. This part of the CNS is routinely used for isolation of NSCs $(76,77)$. The unipotency and migratory properties of NSCs help to repopulate neural cells in the CNS following inflammation $(4,78)$. The potential of NSCs to differentiate into neuroglial cells and oligodendrocytes suggests their application as a beneficial method for the treatment of MS (79-84). NSCs can also be derived from bone marrow, and these cells also exhibit the capacity for neuroglial differentiation $(81,82)$.

\section{ENDOMETRIAL STEM CELLS}

Human endometrium contains a small number of endometrial stem cells (hEnSCs) that can be considered as a source of MSCs for cell-based tissue engineering applications to repair bone, neural cells, osteoblasts, cartilage, and muscle (85). It is well understood that endometrial stem cells (EnSCs) are responsible for the remarkable regenerative capacity of endometrium (86). hEnSCs can differentiate into high-efficiency cholinergic and dopaminergic neurons with confirmed formation of functional neurons (87). EnScs alleviate neuroinflammation through the impairment of Th17 and Thl CD4 cells (88). hEnSCs can be differentiated into Schwann cells (SCs) in both 2D and 3D cultures. These differentiated cells in fibrin gel could present new opportunities for tissue engineering approaches and subsequent treatment of neurodegenerative disorders (89). hEnSCs can differentiate into oligodendrocyte progenitors with characteristic oligodendroglial precursor cells (OPCs) morphology, and express markers such as PDGFRa, Sox10, A2B5, Olig2, and O4 (90). hEnSCs reduced perivascular 
infiltrate and EAE scores, and improved overall tissue appearance (91) in experimental mice. Intravenous or intrathecal administration of hEnSCs to four patients showed a good safety profile. After 1 year of follow-up, the patients showed no immunological reactions or treatment-associated adverse effects; based on radiological and functional assessment as reported by radiologists, no disease progression was observed (92).

\section{EMBRYONIC STEM CELLS}

ESCs are derived from the inner cell mass of blastocyst-stage embryos. ESCs are totipotent cells that can differentiate into all tissues and cell types, including hematopoietic precursors, heart and skeletal muscles, and neural cells. ES cells can be considered as a valuable source of cells for deriving glial precursors that can interact with host neurons and efficiently myelinate axons in brain and spinal cord and also promote improvement of motor function $(93,94)$. Human embryonic stem cells (hESCs) have proved a promising source for the generation and replacement of mature oligodendrocytes (95). Accordingly, hESC-derived oligodendrocytes can play a supportive role in the repair of CNS injuries (96). Intracerebroventricular transplanted hESC-derived oligodendroglial progenitor (hESC-OPs) cells ameliorated the clinical symptoms and promoted recovery from EA E paralysis. EAE mice that received hESC-OPs induced Foxp3-positive T-regulatory cells and produced a new population of TREM2-positive cells that has anti-inflammatory and tissue regeneration promoting properties (97). Also, transplanted hESC-derived neural precursor cells into the brain ventricles significantly reduced the clinical signs of EAE mice. Transplanted neural precursors migrated into the host white matter; however, differentiation into mature oligodendrocytes and remyelination were insignificant (3). In the EAE model of MS, the therapeutic effect of hES-MSCs, including reduction of clinical symptoms and prevention of neuronal demyelination, was significantly higher than BMMSCs (98). Transplantation of ESCs in adult rat spinal cord had the ability to survive, migrate, and differentiate into mature myelin-producing cells in areas of demyelination (99). Clinical reports of transplantation of hESC in patients with MS and Lyme disease have shown remarkable improvement in their functional skills, overall stamina, cognitive abilities, and muscle strength (100).

\section{INDUCED PLURIPOTENT STEM CELLS}

Induced pluripotent stem cells (iPSCs) are generated via reprogramming of mouse fibroblasts into ESCs that overexpress four genes: Sox2,Oct3/4, Klf4, and $c-M y c(101,102)$. iPSCs exhibit similar phenotype of ESC, and proliferate and differentiate into all cell types of the body as well as teratomas formation $(103,104)$. Remyelination activity of iPSCs was assessed in mouse EAE models. The formation of oligoprogenitor cells and myelinating oligodendrocyte confirms the therapeutic effects of cell therapy based on iPSCs. Also, iPSCs have the neuroprotective effects via secretion of growth factors such as LIF that amplify the viability of endogenous oligoprogenitor stem cells and remyelination $(105,106)$. iPS cells can provide the allogeneic and autologous stem cell therapy and hold promise for specific treatment. 


\section{SPERMATOGONIA STEM CELLS}

Spermatogonia stem cells (SSCs) are derived from seminiferous tubules in testes, and in vitro studies show the pluripotency of these cells $(22,107-109)$. They differentiate into ES-like cells, with a similar phenotype and differentiation capacity (110-112). They can be considered an alternative cell source to ESCs without the ethical limitation and immunological problems associated with ESCs. Neural and glial differentiation of ES-like cells derived from testes have been reported by several groups. The efficiency of neural differentiation was confirmed using action potentials recorded by Patch-clamp electrophysiological examinations, and the capacity of SSCs to form functional neurons and oligodendrocytes has been reported. Our findings showed functional recovery and significant remyelination, following transplantation of oligoprogenitor cells derived from mouse SSCs, in an animal model of demyelination (22). Further investigations should be done to confirm the recovery outcome of this novel pluripotent cell source in animal models of MS.

\section{Endogenous Stem Cell Niches Reactivation in MS}

Apart from the exogenous sources of stem cells described above, the endogenous stem cell population opens up a new perspective for MS treatment (113). Studies on patient brain tissue samples and animal models of MS show that in the adult CNS, endogenous regeneration activities exist; however, repair efficacy is low and tends to diminish during disease progression $(114,115)$. Mature oligodendrocytes are extremely degenerative due to primary insult, or secondary to oxidative and excitotoxic stress; thus, they do not participate in myelin repair activities (116). However, resident OPCs (117) or adult neural stem cells (aNSCs) (118-120) become activated and are recruited to lesion sites in order to perform remyelination and restore axonal functionality. There is evidence that OPCs produce the vast majority of remyelinating oligodendrocytes (121), which can also originate from the stem and precursor cells of adult SVZ (122). In response to injury or demyelination, OPCs in the surrounding area convert from a quiescent state to a regenerative phenotype (123). Injury to the CNS activates microglia and astrocyte cell types and disturbs tissue homeostasis, resulting in OPC activation (124). These two cell types are the main factors that induce proliferation and migration of OPCs to the site of injury in demyelinating insults $(124,125)$. During the regeneration phase of demyelination, some factors have been shown to contribute to the regulation of OPC differentiation into myelinating oligodendrocytes (126). Several studies have provided evidence for the inhibitory effects of some factors such as semaphorin 3A (127), Nogo receptor (128), LINGO-1 $(129,130)$, and wnt signaling pathway (131) on OPCs differentiation during development and remyelination. Remyelination can occur in demyelination conditions but is very limited. Remyelination failure is due to the impact of numerous inhibitory mechanisms $(132,133)$. To improve functional recovery, therapeutic approaches should be developed by either potentiating endogenous stem cell populations or by providing exogenous source of repair-mediating cells for the injured CNS. In this section, we describe recent studies related to the 
endogenous stem cells of the central and peripheral nervous systems, and their potential therapeutic application for the treatment of MS.

\section{CNS Neural Stem Cell pools}

Within the adult mammalian brain, NSCs are located in the SVZ of lateral ventricles, hippocampal subgranular zone (SGZ), and the central canal (CC) of the spinal cord where they divide and give rise to new neurons in a process termed adult neurogenesis $(4,134,135)$. Other germinal regions have been identified in the third ventricle, hypothalamus, the subpial layer of the cerebellum, and the meninges $(136,137)$. NSCs located in very specific microenvironments, called niche, and their cellular makeup have been shown to consist of a variety of cells including NSCs and their immature progeny accompanied by endothelial, astroglial, and ependymal cells $(138,139)$. They receive structural and trophic signals from cell-to-cell and cell-to-extracellular matrix (ECM) contact. This communication provides critical spatial and temporal information, which in turn allows stem cells to act in response to both physiological and pathological stimuli $(138,140)$.

\section{SVZ OF LATERAL VENTRICLES}

SVZ is the largest neurogenic niche in the adult CNS that is capable of sustaining neurogenesis throughout life (141). The adult SVZ displays a high degree of organization with stem cells and other cell types which is an important feature of the neurogenic region of SVZ (142). The SVZ is composed of heterogeneous cell types including nondividing ependymal cells (E1) with a large apical surface and multiple long cilia (143), astrocyte-like type B cells (B1) (slow dividing) that give rise to type $C$ cells (fast dividing), which in turn differentiate into neuroblasts (type A) and migrate to olfactory bulb and provide new interneurons $(144,145)$. The en face view of the lateral ventricle revealed that the apical cilium of one or more Bl cells was surrounded by El cells in striking pinwheel architecture which is specific to neurogenic area (142). Bl cells contact the ventricle via their apical cilium and blood vessels at the basal processes. They are quiescent and slowly proliferate in normal condition but can become activated in different pathologies (146).

Intense research in the last decades on animal models of MS and tissue samples of MS patients has shown that the adult SVZ niche is reactivated in response to various types of proximal insults by producing new progenitors that migrate toward the injury site and differentiate into oligodendrocytes (118, 147-149). In addition, it has been reported that type B (150), type C (147), and type A cells (151) have all been indicated as sources of newly generated oligodendrocytes in physiological and pathological conditions. Furthermore, we recently found that ventricular pinwheel organization and structure are modified and El cells are reactivated in response to inflammatory demyelination (152). However, SVZ progenitor's recruitment into the lesion site in the demyelination condition was relatively poor and their differentiation potential to oligodendrocyte is limited because of some inhibitory factors in mature environments during MS. 


\section{SGZ OF THE HIPPOCAMPUS}

The second major region that sustains neurogenesis in the adult brain throughout life is the SGZ of the hippocampus, which is located at the border of the granule cell layer (GCL) and the hilus of dentate gyrus (DG) (153). Neurogenesis in the adult hippocampus occurs throughout life and mainly contributes to the processes involved in learning and memory; however, the ultimate function of neurogenesis in DG remains to be clarified (154). Radial glia-like cells (RGL) in DG represent a quiescent population which may be provoked to generate the proliferative precursors identified as intermediate progenitors, namely, IPCl and IPC2 cells (155). These cells produce novel immature granule neurons (type 3 cells), which migrate into the inner GCL and differentiate into granule cells of the DG (153). They extend their dendrites and axons toward the CA3 region and become functionally integrated into host circuitry (119).

Cognitive impairment and memory dysfunction affect more than 60\% of MS patients (156). It has been reported that cognitive dysfunction is correlated with hippocampal demyelination (157). Although the molecular mechanisms that control hippocampal NSC proliferation and differentiation in physiology and pathological conditions are unknown, recent findings reveal that acute inflammatory demyelination in animal model of MS could provoke the hippocampal stem cell niche and enhance proliferation of NPCs in SGZ (158). Thus, inflammatory factors such as cytokines and chemokines can affect the proliferative capacity of NSCs and alter neurogenesis in the SGZ (159). Huehnchen et al. (2011) reported that NPC proliferation in the DG increases not only in the acute phase but also in the chronic phase of the disease(160). Furthermore, it has been found that the neurogenic niche of the hippocampus was reactivated in animal models of MS (161).

\section{CENTRAL CANAL OF THE SPINAL CORD}

The spinal cord is the caudal part of CNS that consists of 33 nerve segments, from the cervical to coccygeal sections. There is a central canal at the center of the spinal cord which contains the cerebrospinal fluid (CSF) (134). The ependymal layer of the spinal cord has an important role in embryonic development and is well known for its function as a neuroprogenitor niche (162). In the late 1990s, multipotent stem cells were discovered in the adult mammalian spinal cord. Isolated NSC from central canal of rat and mouse can produce neurospheres that are able to self-renew, proliferate, and differentiate into the three major CNS cell types (163). Moreover, it was shown that NSC resides at the central canal and is able to selfrenew and generate mature oligodendrocytes during injury (164). The adult central canal stem cells are quiescent under physiological conditions; however, some proliferation has been observed at the dorsal and ventral tip of the CC that contacts the lumen or the subependymal position $(135,164)$. Dorsal ependymal cells show radial glial morphology and express GFAP, nestin, CD15, and/or brain lipid-binding protein (BLBP) (165). It has currently been shown that ependymal cells at both dorsal and ventral point of the central canal are able to generate progeny of multiple fates under physiological and pathological conditions (166). Further research is needed to fully unravel the neurogenic properties and/or potential of the central canal in MS. 


\section{OTHER GERMINAL AREAS OF THE CNS}

Beyond the classic NSC niches referenced above, other germinal niches have been identified. These germinal regions include the hypothalamus, the third ventricle, the meninges, and the subpial layer of the cerebellum (167). The parenchyma of the cerebral cortex and spinal cord are mainly comprised of restricted neuroglia precursors and these niche are referred to as nongerminal regions of CNS (168). These neurogenic niches are composed of a heterogeneous population of NSC that is able to self-renew and give rise to most of the neuronal and glial precursors (4). Several studies showed that the third ventricle and hypothalamus neurogenic zone contain multipotent cells that can give rise to neurons, oligodendrocytes, and astrocytes in vitro and in vivo (169-171). Xu and others reported that the third ventricle ependymal layer cells were able to migrate into hypothalamic parenchymal regions and differentiate into functional neurons in response to injury (172). Our previous study also showed that progenitor cells in the third ventricle surroundings could be reactivated by local demyelination in the optic chiasm (128, 171). Also nestin and DCX-positive cells have been found in the meninges of the brain and spinal cord $(138,173)$. We concluded that there are widespread sources of stem cells in the CNS that can be activated in different pathological situations, especially in MS.

\section{Peripheral Endogenous Stem Cells and Their Role in MS}

\section{SCHWANN CELLS}

In the peripheral nervous system (PNS), a different source of cells has been identified that can be used for the treatment of CNS diseases like MS. SCs have been intensely studied in CNS repair and have been shown to support and myelinate regenerating axons (174). Several studies that transplanted neonate or adult SCs in different animal models of CNS demyelination had shown that SCs efficiently remyelinate CNS axons (175). The myelin formed by a grafted SC was stable for up to 5 months post-graft and improved conduction of demyelinated axons $(176,177)$. Neuroregenerative effect of SCs has also been reported in spinal trauma models which highlighted the ability of these cells to regenerate axons in the injured area (178). However, the important limitation concerning the use of SCs as a therapeutic approach to promote remyelination in MS is their inability to migrate efficiently when grafted in injured CNS (179). Modifying SC-intrinsic properties, like boosting expression of neurotrophins (e.g., BDNF and NT3), promote SC migration and myelinating potentials $(180,181)$. Also, SC-mediated myelination and axonal regeneration increased when the environment of the SC was modified (182).

\section{OLFACTORY ENSHEATHING CELLS}

Olfactory ensheathing cells (OEC) are very similar to SCs and belong to the peripheral olfactory system that ensheathes the axon of the first cranial nerve but does not myelinate it (183). Recently, it was shown that the origin of OEC 
during development was from neural crest cells (NCCs) (184). Although OEC does not usually myelinate axons of the first cranial nerve, the vast studies have shown that OECs are capable of extensive functional remyelination when grafted into demyelinated lesions $(185,186)$. Numerous studies proposed that OEC migrates better than SC when faced with CNS elements $(187,188)$. From a therapeutic point of view, OEC transplantation appears to be better than SC.

\section{PNS PROGENITORS}

PNS progenitors include Schwann cell precursors (SCps), boundary cap cells (BCs), and olfactory epithelial progenitors (OEps) that all originate from NCCs (175). It has been reported that SCp has greater capacity for remyelination after grafting in demyelinated CNS or spinal cord injury (189). BC is the potential stem cell of spinal roots (190) that could migrate freely in the demyelinated CNS and compete with endogenous myelin-forming cells to remyelinate axons of far distant lesions (191). BC can also differentiate into central myelin-forming cells in vitro and in vivo (192). OEp was extracted from olfactory epithelium with a less invasive method and when pieces of olfactory lamina containing OEp were grafted into injured rat spinal cord, they promoted functional recovery in paraplegic rats (193). OEp provided extensive remyelination upon transplantation into demyelinated lesion (194).

\section{Endogenous Neural Stem Cell Niche Modulation as a Therapeutic Approach}

The niche microenvironment regulates NSC survival, proliferation, and differentiation during health and disease $(142,152)$. Therefore, different molecular strategies have been studied in an effort to enhance the NSC niche potential for facilitating repair and aiding in functional recovery of various neurodegenerative disorders by using new pharmacological targets (138). Administration of exogenous growth factors such as EGF, PEDF, HGF, and CNTF in mice has been reported to enhance NSC proliferation $(195,197)$. In addition, other factors such as bFGF, EGF, and BDNF have also been shown to enhance neurogenesis and eventually enhance functional recovery in animal models of neurological disease (198-200). Administration of valproic acid has been shown to attenuate symptoms of EAE, and increase endogenous myelin repair by recruiting NSCs and oligodendrocyte progenitors to the lesion sites (201). Moreover, treatment of EAE animals with polymerized nanocurcumin showed promising results in enhancing neuroprotection and myelin repair (202). Certain antidepressants like fluoxetine have been revealed to be capable of increasing neurogenesis (203). Administration of small interfering RNA (siRNA) or specific antibodies against various inhibitory targets such as Nogo, Nogo receptor (NgR), LINGOl, and Sema3A in different animal models of MS and spinal cord injury enhance proliferation, migration, and differentiation potential of endogenous stem cells and facilitate axonal regeneration, myelin repair, and functional recovery $(128,204-207)$. Khezri and coworkers reported that administration of cyclic AMP inhibits the progression of EAE disease and potentiates recruitment of endogenous NSCs and myelin repair (208). 


\section{Conclusion}

The existence of NSCs and neurogenic niches in the adult mammalian CNS is clearly recognized. The functional implication of adult neurogenesis and gliogenesis continues to grow as new researches describe their critical roles in both health and disease. In spite of this growing body of evidence and progress in our understanding of NSC and niche functions in physiological and pathologic situations, several critical issues remain to be answered. The main issue is the translational relevance of the basic biology, that has been described in animal models, to human neurogenesis, and clinical trials. Moreover, the ultimate molecular mechanisms that influence endogenous stem cell migration will also be a key in developing appropriate treatments and strategies to prevent, alleviate, and treat MS. Further studies to identify the definitive nature, location, and behavior of NSC are warranted to realize the full therapeutic potential of these stem cells for the treatment of MS.

Conflict of interest: The authors declare no potential conflicts of interest with respect to research, authorship, and/or publication of this chapter.

Copyright and permission statement: To the best of our knowledge, the materials included in this chapter do not violate copyright laws. All original sources have been appropriately acknowledged and/or referenced. Where relevant, appropriate permissions have been obtained from the original copyright holder(s).

\section{References}

1. Chiaravalloti ND, DeLuca J. Cognitive impairment in multiple sclerosis. Lancet Neurol. 2008;7(12):1139-51. http://dx.doi.org/10.1016/S1474-4422(08)70259-X

2. Wingerchuk DM, Carter JL.Multiple sclerosis: current and emerging disease-modifying therapies and treatment strategies. Mayo Clin Proc. 2014 Feb;89(2):225-40

3. Aharonowiz M, Einstein O, Fainstein N, Lassmann H, Reubinoff B, Ben-Hur T. Neuroprotective effect of transplanted human embryonic stem cell-derived neural precursors in an animal model of multiple sclerosis. PLoS One. 2008;3(9):e3145. http://dx.doi.org/10.1371/journal.pone.0003145

4. Pluchino S, Martino G. The therapeutic plasticity of neural stem/precursor cells in multiple sclerosis. J Neurol Sci. 2008;265(1):105-10. http://dx.doi.org/10.1016/j.jns.2007.07.020

5. Rice CM, Kemp K, Wilkins A, Scolding NJ. Cell therapy for multiple sclerosis: An evolving concept with implications for other neurodegenerative diseases. Lancet. 2013;382(9899):1204-13. http:// dx.doi.org/10.1016/S0140-6736(13)61810-3

6. Akiyama K, You Y-O, Yamaza T, Chen C, Tang L, Jin Y, et al. Characterization of bone marrow derived mesenchymal stem cells in suspension. Stem Cell Res Ther. 2012;3(5):40. http://dx.doi.org/10.1186/ scrt131

7. Cristofanilli M, Harris VK, Zigelbaum A, Goossens AM, Lu A, Rosenthal H, et al. Mesenchymal stem cells enhance the engraftment and myelinating ability of allogeneic oligodendrocyte progenitors in dysmyelinated mice. Stem Cells Dev. 2011;20(12):2065-76. http://dx.doi.org/10.1089/ scd.2010.0547

8. Connick P, Kolappan M, Crawley C, Webber DJ, Patani R, Michell AW, et al. Autologous mesenchymal stem cells for the treatment of secondary progressive multiple sclerosis: An open-label phase 2a proof-of-concept study. Lancet Neurol. 2012;11(2):150-6. http://dx.doi.org/10.1016/ S1474-4422(11)70305-2 
9. Jaramillo-Merchan J, Jones J, Ivorra J, Pastor D, Viso-León M, Armengól JA, et al. Mesenchymal stromal-cell transplants induce oligodendrocyte progenitor migration and remyelination in a chronic demyelination model. Cell Death Dis. 2013;4(8):e779. http://dx.doi.org/10.1038/cddis.2013.304

10. Gerdoni E, Gallo B, Casazza S, Musio S, Bonanni I, Pedemonte E, et al. Mesenchymal stem cells effectively modulate pathogenic immune response in experimental autoimmune encephalomyelitis. Ann Neurol. 2007;61(3):219-27. http://dx.doi.org/10.1002/ana.21076

11. Rafei M, Campeau PM, Aguilar-Mahecha A, Buchanan M, Williams P, Birman E, et al. Mesenchymal stromal cells ameliorate experimental autoimmune encephalomyelitis by inhibiting CD4 Th17 T cells in a CC chemokine ligand 2-dependent manner. J Immunol. 2009;182(10):5994-6002. http://dx.doi. org/10.4049/jimmunol.0803962

12. Zappia E, Casazza S, Pedemonte E, Benvenuto F, Bonanni I, Gerdoni E, et al. Mesenchymal stem cells ameliorate experimental autoimmune encephalomyelitis inducing T-cell anergy. Blood. 2005;106(5):1755-61. http://dx.doi.org/10.1182/blood-2005-04-1496

13. Bai L, Lennon DP, Eaton V, Maier K, Caplan AI, Miller SD, et al. Human bone marrow-derived mesenchymal stem cells induce Th2-polarized immune response and promote endogenous repair in animal models of multiple sclerosis. Glia. 2009;57(11):1192-203. http://dx.doi.org/10.1002/glia.20841

14. Güttinger M, Fedele D, Koch P, Padrun V, Pralong WF, Brüstle O, et al. Suppression of kindled seizures by paracrine adenosine release from stem cell-derived brain implants. Epilepsia. 2005;46(8):1162-9. http://dx.doi.org/10.1111/j.1528-1167.2005.61804.x

15. Tanna T, Sachan V. Mesenchymal stem cells: Potential in treatment of neurodegenerative diseases. Curr Stem Cell Res Ther. 2014;9(6):513-21. http://dx.doi.org/10.2174/1574888X09666140923101110

16. Woodbury D, Schwarz EJ, Prockop DJ, Black IB. Adult rat and human bone marrow stromal cells differentiate into neurons. J Neurosci Res. 2000;61(4):364-70. http://dx.doi. org/10.1002/1097-4547(20000815)61:4\%3C364::AID-JNR2\%3E3.0.CO;2-C

17. Harris VK, Yan QJ, Vyshkina T, Sahabi S, Liu X, Sadiq SA. Clinical and pathological effects of intrathecal injection of mesenchymal stem cell-derived neural progenitors in an experimental model of multiple sclerosis. J Neurol Sci. 2012;313(1):167-77. http://dx.doi.org/10.1016/j.jns.2011.08.036

18. Karussis D, Karageorgiou C, Vaknin-Dembinsky A, Gowda-Kurkalli B, Gomori JM, Kassis I, et al. Safety and immunological effects of mesenchymal stem cell transplantation in patients with multiple sclerosis and amyotrophic lateral sclerosis. Arch Neurol. 2010;67(10):1187-94. http://dx.doi. org/10.1001/archneurol.2010.248

19. Dazzi F, Krampera M. Mesenchymal stem cells and autoimmune diseases. Best Pract Res Clin Haematol. 2011;24(1):49-57. http://dx.doi.org/10.1016/j.beha.2011.01.002

20. Slavin S, Kurkalli BG, Karussis D. The potential use of adult stem cells for the treatment of multiple sclerosis and other neurodegenerative disorders. Clin Neurol Neurosurg. 2008;110(9):943-6. http:// dx.doi.org/10.1016/j.clineuro.2008.01.014

21. Minagar A. Current and future therapies for multiple sclerosis. Scientifica. 2013;2013:249101. http:// dx.doi.org/10.1155/2013/249101

22. Bojnordi MN, Ghasemi H, Akbari E. Remyelination after lysophosphatidyl choline-induced demyelination is stimulated by bone marrow stromal cell-derived oligoprogenitor cell transplantation. Cells Tissues Organs. 2014;200(5):300-6. http://dx.doi.org/10.1159/000437350

23. Wilkins A, Kemp K, Ginty M, Hares K, Mallam E, Scolding N. Human bone marrow-derived mesenchymal stem cells secrete brain-derived neurotrophic factor which promotes neuronal survival in vitro. Stem Cell Res. 2009;3(1):63-70. http://dx.doi.org/10.1016/j.scr.2009.02.006

24. Wislet-Gendebien S, Hans G, Leprince P, Rigo JM, Moonen G, Rogister B. Plasticity of cultured mesenchymal stem cells: Switch from nestin-positive to excitable neuron-like phenotype. Stem Cells. 2005;23(3):392-402. http://dx.doi.org/10.1634/stemcells.2004-0149

25. Parr AM, Tator $\mathrm{CH}$, Keating A. Bone marrow-derived mesenchymal stromal cells for the repair of central nervous system injury. Bone Marrow Transplant. 2007;40(7):609. http://dx.doi.org/10.1038/ sj.bmt. 1705757

26. Lanza C, Morando S, Voci A, Canesi L, Principato MC, Serpero LD, et al. Neuroprotective mesenchymal stem cells are endowed with a potent antioxidant effect in vivo. J Neurochem. 2009;110(5): 1674-84. http://dx.doi.org/10.1111/j.1471-4159.2009.06268.x 
27. Beyth S, Borovsky Z, Mevorach D, Liebergall M, Gazit Z, Aslan H, et al. Human mesenchymal stem cells alter antigen-presenting cell maturation and induce T-cell unresponsiveness. Blood. 2005;105(5):2214-19. http://dx.doi.org/10.1182/blood-2004-07-2921

28. Spaggiari GM, Capobianco A, Becchetti S, Mingari MC, Moretta L. Mesenchymal stem cell-natural killer cell interactions: Evidence that activated NK cells are capable of killing MSCs, whereas MSCs can inhibit IL-2-induced NK-cell proliferation. Blood. 2006;107(4):1484-90. http://dx.doi. org/10.1182/blood-2005-07-2775

29. Zhang H, Huang Z, Xu Y, Zhang S. Differentiation and neurological benefit of the mesenchymal stem cells transplanted into the rat brain following intracerebral hemorrhage. Neurol Res. 2006;28(1): 104-12. http://dx.doi.org/10.1179/016164106X91960

30. Dulamea A. Mesenchymal stem cells in multiple sclerosis-translation to clinical trials. J Med Life. 2015;8(1):24.

31. Fassas A, Anagnostopoulos A, Kazis A, Kapinas K, Sakellari I, Kimiskidis V, et al. Peripheral blood stem cell transplantation in the treatment of progressive multiple sclerosis: First results of a pilot study. Bone Marrow Transplant. 1997;20(8):631-8. http://dx.doi.org/10.1038/sj.bmt.1700944

32. Xu J, Ji B-x, Su L, Dong H-q, Sun X-J, Liu C-Y. Clinical outcomes after autologous haematopoietic stem cell transplantation in patients with progressive multiple sclerosis. Chin Med J. 2006;119(22):1851-5.

33. Guimarães FA, Oliveira-Cardoso ÉA, Mastropietro AP, Voltarelli JC, Santos MA. Impact of autologous hematopoetic stem cell transplantation on the quality of life of patients with multiple sclerosis. Arq Neuropsiquiatr. 2010;68(4):522-7. http://dx.doi.org/10.1590/S0004-282X2010000400009

34. van Bekkum DW. Preclinical experiments. Best Pract Res Clin Haematol. 2004;17(2):201-22. http:// dx.doi.org/10.1016/j.beha.2004.04.003

35. Van Gelder M, Van Bekkum D. Treatment of relapsing experimental autoimmune encephalomyelitis in rats with allogeneic bone marrow transplantation from a resistant strain. Bone Marrow Transplant. 1995;16(3):343-51.

36. Saiz A, Carreras E, Berenguer J, Yagüe J, Martinez C, Marin P, et al. MRI and CSF oligoclonal bands after autologous hematopoietic stem cell transplantation in MS. Neurol. 2001;56(8):1084-9. http:// dx.doi.org/10.1212/WNL.56.8.1084

37. Lu J-Q, Storek J, Metz L, Yong VW, Stevens AM, Nash RA, et al. Continued disease activity in a patient with multiple sclerosis after allogeneic hematopoietic cell transplantation. Arch Neurol. 2009;66(1):116-20. http://dx.doi.org/10.1001/archneurol.2008.522

38. Rabusin M, Snowden J, Veys P, Quartier P, Dalle J-H, Dhooge C, et al. Long-term outcomes of hematopoietic stem cell transplantation for severe treatment-resistant autoimmune cytopenia in children. Biol Blood Marrow Transplant. 2013;19(4):666-9. http://dx.doi.org/10.1016/j.bbmt. 2012.12.008

39. Shevchenko JL, Kuznetsov AN, Ionova TI, Melnichenko VY, Fedorenko DA, Kartashov AV, et al. Autologous hematopoietic stem cell transplantation with reduced-intensity conditioning in multiple sclerosis. Exp Hematol. 2012;40(11):892-8. http://dx.doi.org/10.1016/j.exphem.2012.07.003

40. Tyndall A, Matucci-Cerinic M. Haematopoietic stem cell transplantation for the treatment of systemic sclerosis and other autoimmune disorders. Exp Opin Biol Ther. 2003;3(7):1041-9. http://dx.doi. org/10.1517/14712598.3.7.1041

41. Weissman IL, Shizuru JA. The origins of the identification and isolation of hematopoietic stem cells, and their capability to induce donor-specific transplantation tolerance and treat autoimmune diseases. Blood. 2008;112(9):3543-53. http://dx.doi.org/10.1182/blood-2008-08-078220

42. Pasquini MC, Voltarelli J, Atkins HL, Hamerschlak N, Zhong X, Ahn KW, et al. Transplantation for autoimmune diseases in north and South America: A report of the Center for International Blood and Marrow Transplant Research. Biol Blood Marr Transplant. 2012;18(10):1471-8. http://dx.doi. org/10.1016/j.bbmt.2012.06.003

43. Capobianco M, Motuzova Y, Frau J, Cocco E, Mamusa E, Marrosu M, et al. Natalizumab in aggressive multiple sclerosis after haematopoietic stem cell transplantation. Neurol Sci. 2012;33(4):863-7. http://dx.doi.org/10.1007/s10072-011-0848-1

44. Mancardi G, Sormani M, Di Gioia M, Vuolo L, Gualandi F, Amato M, et al. Autologous haematopoietic stem cell transplantation with an intermediate intensity conditioning regimen in multiple 
sclerosis: The Italian multi-centre experience. Mult Scler J. 2012;18(6):835-42. http://dx.doi.org/10. $1177 / 1352458511429320$

45. Reston JT, Uhl S, Treadwell JR, Nash RA, Schoelles K. Autologous hematopoietic cell transplantation for multiple sclerosis: A systematic review. Mult Scler J. 2011;17(2):204-13. http://dx.doi.org/10. $1177 / 1352458510383609$

46. Ding D-C, Chang Y-H, Shyu W-C, Lin S-Z. Human umbilical cord mesenchymal stem cells: A new era for stem cell therapy. Cell Transplant. 2015;24(3):339-47. http://dx.doi.org/10.3727/096 $368915 \times 686841$

47. Fan C-G, Zhang Q-j, Zhou J-r. Therapeutic potentials of mesenchymal stem cells derived from human umbilical cord. Stem Cell Rev Rep. 2011;7(1):195-207. http://dx.doi.org/10.1007/s12 015-010-9168-8

48. Baksh D, Yao R, Tuan RS. Comparison of proliferative and multilineage differentiation potential of human mesenchymal stem cells derived from umbilical cord and bone marrow. Stem Cells. 2007;25(6):1384-92. http://dx.doi.org/10.1634/stemcells.2006-0709

49. Chen M-Y, Lie P-C, Li Z-L, Wei X. Endothelial differentiation of Wharton's jelly-derived mesenchymal stem cells in comparison with bone marrow-derived mesenchymal stem cells. Exp Hematol. 2009;37(5):629-40. http://dx.doi.org/10.1016/j.exphem.2009.02.003

50. Liu R, Zhang Z, Lu Z, Borlongan C, Pan J, Chen J, et al. Human umbilical cord stem cells ameliorate experimental autoimmune encephalomyelitis by regulating immunoinflammation and remyelination. Stem Cells Dev. 2012;22(7):1053-62. http://dx.doi.org/10.1089/scd.2012.0463

51. Liang J, Zhang H, Hua B, Wang H, Wang J, Han Z, et al. Allogeneic mesenchymal stem cells transplantation in treatment of multiple sclerosis. Mult Scler J. 2009;15(5):644-6. http://dx.doi.org/10. $1177 / 1352458509104590$

52. Li J-F, Zhang D-J, Geng T, Chen L, Huang H, Yin H-L, et al. The potential of human umbilical cordderived mesenchymal stem cells as a novel cellular therapy for multiple sclerosis. Cell Transplant. 2014;23(1):S113-22. http://dx.doi.org/10.3727/096368914X685005

53. Hou Z-L, Liu Y, Mao X-H, Wei C-Y, Meng M-Y, Liu Y-H, et al. Transplantation of umbilical cord and bone marrow-derived mesenchymal stem cells in a patient with relapsing-remitting multiple sclerosis. Cell Adh Migr. 2013;7(5):404-7. http://dx.doi.org/10.4161/cam.26941

54. Frausin S, Viventi S, Falzacappa LV, Quattromani MJ, Leanza G, Tommasini A, et al. Wharton's jelly derived mesenchymal stromal cells: Biological properties, induction of neuronal phenotype and current applications in neurodegeneration research. Acta Histochem. 2015;117(4):329-38. http:// dx.doi.org/10.1016/j.acthis.2015.02.005

55. Karahuseyinoglu S, Cinar O, Kilic E, Kara F, Akay GG, Demiralp DÖ, et al. Biology of stem cells in human umbilical cord stroma: In situ and in vitro surveys. Stem Cells. 2007;25(2):319-31. http:// dx.doi.org/10.1634/stemcells.2006-0286

56. Sarugaser R, Lickorish D, Baksh D, Hosseini MM, Davies JE. Human umbilical cord perivascular (HUCPV) cells: A source of mesenchymal progenitors. Stem Cells. 2005;23(2):220-9. http://dx.doi. org/10.1634/stemcells.2004-0166

57. Zhou C, Yang B, Tian Y, Jiao H, Zheng W, Wang J, et al. Immunomodulatory effect of human umbilical cord Wharton's jelly-derived mesenchymal stem cells on lymphocytes. Cell Immunol. 2011;272(1):33-8. http://dx.doi.org/10.1016/j.cellimm.2011.09.010

58. Peng J, Wang Y, Zhang L, Zhao B, Zhao Z, Chen J, et al. Human umbilical cord Wharton's jellyderived mesenchymal stem cells differentiate into a Schwann-cell phenotype and promote neurite outgrowth in vitro. Brain Res Bull. 2011;84(3):235-43. http://dx.doi.org/10.1016/j.brainresbull. 2010.12.013

59. Agah EM, Parivar K, Joghataei MT. Therapeutic effect of transplanted human Wharton's jelly stem cell-derived oligodendrocyte progenitor cells (hWJ-MSC-derived OPCs) in an animal model of multiple sclerosis. Mol Neurobiol. 2014;49(2):625-32. http://dx.doi.org/10.1007/s12035-013-8543-2

60. Donders R, Vanheusden M, Bogie JF, Ravanidis S, Thewissen K, Stinissen P, et al. Human Wharton's jelly-derived stem cells display immunomodulatory properties and transiently improve rat experimental autoimmune encephalomyelitis. Cell transplantation. 2015;24(10):2077-98. http://dx.doi. org/10.3727/096368914X685104 
61. Gimble J, Guilak F. Adipose-derived adult stem cells: Isolation, characterization, and differentiation potential. Cytotherapy. 2003;5(5):362-9. http://dx.doi.org/10.1080/14653240310003026

62. Zuk PA, Zhu M, Ashjian P, De Ugarte DA, Huang JI, Mizuno H, et al. Human adipose tissue is a source of multipotent stem cells. Mol Biol Cell. 2002;13(12):4279-95. http://dx.doi.org/10.1091/ mbc.E02-02-0105

63. Ra JC, Kang SK, Shin IS, Park HG, Joo SA, Kim JG, et al. Stem cell treatment for patients with autoimmune disease by systemic infusion of culture-expanded autologous adipose tissue derived mesenchymal stem cells. J Trans Med. 2011;9(1):181.

64. Chen HT, Lee MJ, Chen CH, Chuang SC, Chang LF, Ho ML, et al. Proliferation and differentiation potential of human adipose-derived mesenchymal stem cells isolated from elderly patients with osteoporotic fractures. J Cell Mol Med. 2012;16(3):582-92. http://dx.doi.org/10.1111/j.1582-4934. 2011.01335.x

65. Marconi S, Castiglione G, Turano E, Bissolotti G, Angiari S, Farinazzo A, et al. Human adiposederived mesenchymal stem cells systemically injected promote peripheral nerve regeneration in the mouse model of sciatic crush. Tissue Eng A. 2012;18(11-12):1264-72. http://dx.doi.org/10.1089/ ten.tea.2011.0491

66. Strong AL, Bowles AC, Wise RM, Morand JP, Dutreil MF, Gimble JM, et al. Human adipose stromal/ stem cells from obese donors show reduced efficacy in halting disease progression in the experimental autoimmune encephalomyelitis model of multiple sclerosis. Stem Cells. 2016;34(3):614-26. http:// dx.doi.org/10.1002/stem.2272

67. Anghileri E, Marconi S, Pignatelli A, Cifelli P, Galie M, Sbarbati A, et al. Neuronal differentiation potential of human adipose-derived mesenchymal stem cells. Stem Cells Dev. 2008;17(5):909-16. http://dx.doi.org/10.1089/scd.2007.0197

68. Yousefi F, Ebtekar M, Soleimani M, Soudi S, Hashemi SM. Comparison of in vivo immunomodulatory effects of intravenous and intraperitoneal administration of adipose-tissue mesenchymal stem cells in experimental autoimmune encephalomyelitis (EAE). Int Immunopharmacol. 2013;17(3):608-16. http://dx.doi.org/10.1016/j.intimp.2013.07.016

69. Constantin G, Marconi S, Rossi B, Angiari S, Calderan L, Anghileri E, et al. Adipose-derived mesenchymal stem cells ameliorate chronic experimental autoimmune encephalomyelitis. Stem Cells. 2009;27(10):2624-35. http://dx.doi.org/10.1002/stem.194

70. Anderson P, Gonzalez-Rey E, O'Valle F, Martin F, Oliver FJ, Delgado M. Allogeneic Adipose-Derived Mesenchymal Stromal Cells Ameliorate Experimental Autoimmune Encephalomyelitis by Regulating Self-Reactive T Cell Responses and Dendritic Cell Function. Stem Cells Int. 2017 (2017).1-15

71. Kashani IR, Hedayatpour A, Pasbakhsh P, Kafami L, Atlasi N, Mahabadi VP, et al. 17 [Beta]-estradiol enhances the efficacy of adipose-derived mesenchymal stem cells on remyelination in mouse model of multiple sclerosis. Acta Med Iran. 2012;50(12):689.

72. Mohammadzadeh A, Pourfathollah AA, Shahrokhi S, Hashemi SM, Moradi SLA, Soleimani M. Immunomodulatory effects of adipose-derived mesenchymal stem cells on the gene expression of major transcription factors of T cell subsets. Int Immunopharmacol. 2014;20(2):316-21. http:// dx.doi.org/10.1016/j.intimp.2014.03.003

73. Shalaby SM, Sabbah NA, Saber T, Abdel Hamid RA. Adipose-derived mesenchymal stem cells modulate the immune response in chronic experimental autoimmune encephalomyelitis model. IUBMB Life. 2016;68(2):106-15. http://dx.doi.org/10.1002/iub.1469

74. Mohammadzadeh A, Pourfathollah AA, Shahrokhi S, Fallah A, Tahoori MT, Amari A, et al. Evaluation of AD-MSC (adipose-derived mesenchymal stem cells) as a vehicle for IFN- $\beta$ delivery in experimental autoimmune encephalomyelitis. Clin Immunol. 2016;169:98-106. http://dx.doi.org/10.1016/j. clim.2016.06.015

75. Payne NL, Sun G, McDonald C, Moussa L, Emerson-Webber A, Loisel-Meyer S, et al. Human adiposederived mesenchymal stem cells engineered to secrete IL-10 inhibit APC function and limit CNS autoimmunity. Brain Behav Immun. 2013;30:103-14. http://dx.doi.org/10.1016/j.bbi.2013.01.079

76. Weiss S, Dunne C, Hewson J, Wohl C, Wheatley M, Peterson AC, et al. Multipotent CNS stem cells are present in the adult mammalian spinal cord and ventricular neuroaxis. J Neurosci. 1996;16(23):7599-609. 
77. Garzón-Muvdi T, Quiñones-Hinojosa A. Neural stem cell niches and homing: Recruitment and integration into functional tissues. ILAR J. 2010;51(1):3-23. http://dx.doi.org/10.1093/ilar.51.1.3

78. Brundin L, Brismar H, Danilov AI, Olsson T, Johansson CB. Neural stem cells: A potential source for remyelination in neuroinflammatory disease. Brain Pathol. 2003;13(3):322-8. http://dx.doi. org/10.1111/j.1750-3639.2003.tb00031.x

79. Yandava BD, Billinghurst LL, Snyder EY. "Global" cell replacement is feasible via neural stem cell transplantation: Evidence from the dysmyelinated shiverer mouse brain. Proc Natl Acad Sci U S A. 1999;96(12):7029-34. http://dx.doi.org/10.1073/pnas.96.12.7029

80. Lindvall O, Kokaia Z. Stem cells for the treatment of neurological disorders. Nature. 2006;441(7097):1094. http://dx.doi.org/10.1038/nature04960

81. Ben-Hur T, Einstein O, Mizrachi-Kol R, Ben-Menachem O, Reinhartz E, Karussis D, et al. Transplanted multipotential neural precursor cells migrate into the inflamed white matter in response to experimental autoimmune encephalomyelitis. Glia. 2003;41(1):73-80. http://dx.doi.org/10.1002/glia.10159

82. Heffernan C, Sumer H, Guillemin GJ, Manuelpillai U, Verma PJ. Design and screening of a glial cell-specific, cell penetrating peptide for therapeutic applications in multiple sclerosis. PLoS One. 2012;7(9):e45501. http://dx.doi.org/10.1371/journal.pone.0045501

83. Carbajal KS, Weinger JG, Whitman LM, Schaumburg CS, Lane TE. Surgical transplantation of mouse neural stem cells into the spinal cords of mice infected with neurotropic mouse hepatitis virus. J Vis Exp. 2011;(53):2834. http://dx.doi.org/10.3791/2834

84. Giannakopoulou A, Grigoriadis N, Polyzoidou E, Touloumi O, Michaloudi E, Papadopoulos GC. Inflammatory changes induced by transplanted neural precursor cells in a multiple sclerosis model. NeuroReport. 2011;22(2):68-72. http://dx.doi.org/10.1097/WNR.0b013e32834272eb

85. Gargett CE, Schwab KE, Zillwood RM, Nguyen HP, Wu D. Isolation and culture of epithelial progenitors and mesenchymal stem cells from human endometrium. Biol Reprod. 2009;80(6):1136-45. http://dx.doi.org/10.1095/biolreprod.108.075226

86. Gargett CE. Identification and characterisation of human endometrial stem/progenitor cells. Aust N Z J Obstet Gynaecol. 2006;46(3):250-3. http://dx.doi.org/10.1111/j.1479-828X.2006.00582.x

87. Navaei-Nigjeh M, Amoabedini G, Noroozi A, Azami M, Asmani MN, Ebrahimi-Barough S, et al. Enhancing neuronal growth from human endometrial stem cells derived neuron-like cells in threedimensional fibrin gel for nerve tissue engineering. J Biomed Mater Res A. 2014;102(8):2533-43. http://dx.doi.org/10.1002/jbm.a.34921

88. Ghobadi F, Mehrabani D, Mehrabani G. Regenerative potential of endometrial stem cells: A mini review. World J Plast Surg. 2015;4(1):3.

89. Bayat N, Ebrahimi-Barough S, Ardakan MMM, Ai J. Human endometrial stem cells may differentiate into schwann cells in fibrin gel as 3D culture. Neurosci Med. 2015;6(04):160. http://dx.doi. org/10.4236/nm.2015.64024

90. Ebrahimi-Barough S, Kouchesfahani HM, Ai J, Massumi M. Differentiation of human endometrial stromal cells into oligodendrocyte progenitor cells (OPCs). J Mol Neurosci. 2013;51(2):265-73. http://dx.doi.org/10.1007/s12031-013-9957-z

91. Peron J, Jazedje T, Brandao W, Perin P, Maluf M, Evangelista L, et al. Human endometrial-derived mesenchymal stem cells suppress inflammation in the central nervous system of EAE mice. Stem Cell Rev Rep. 2012;8(3):940-52. http://dx.doi.org/10.1007/s12015-011-9338-3

92. Zhong Z, Patel AN, Ichim TE, Riordan NH, Wang H, Min W-P, et al. Feasibility investigation of allogeneic endometrial regenerative cells. J Trans Med. 2009;7(1):15. http://dx.doi.org/10.1186/1479-5876-7-15

93. Brüstle O, Jones KN, Learish RD, Karram K, Choudhary K, Wiestler OD, et al. Embryonic stem cellderived glial precursors: A source of myelinating transplants. Science. 1999;285(5428):754-6. http:// dx.doi.org/10.1126/science.285.5428.754

94. Keirstead HS, Nistor G, Bernal G, Totoiu M, Cloutier F, Sharp K, et al. Human embryonic stem cellderived oligodendrocyte progenitor cell transplants remyelinate and restore locomotion after spinal cord injury. J Neurosci. 2005;25(19):4694-705. http://dx.doi.org/10.1523/JNEUROSCI.0311-05.2005

95. Nistor GI, Totoiu MO, Haque N, Carpenter MK, Keirstead HS. Human embryonic stem cells differentiate into oligodendrocytes in high purity and myelinate after spinal cord transplantation. Glia. 2005;49(3):385-96. http://dx.doi.org/10.1002/glia.20127 
96. Alsanie WF, Niclis JC, Petratos S. Human embryonic stem cell-derived oligodendrocytes: Protocols and perspectives. Stem Cells Dev. 2013;22(18):2459-76. http://dx.doi.org/10.1089/scd.2012.0520

97. Kim H, Walczak P, Kerr C, Galpoththawela C, Gilad AA, Muja N, et al. Immunomodulation by transplanted human embryonic stem cell-derived oligodendroglial progenitors in experimental autoimmune encephalomyelitis. Stem Cells. 2012;30(12):2820-9. http://dx.doi.org/10.1002/stem.1218

98. Wang X, Kimbrel EA, Ijichi K, Paul D, Lazorchak AS, Chu J, et al. Human ESC-derived MSCs outperform bone marrow MSCs in the treatment of an EAE model of multiple sclerosis. Stem Cell Rep. 2014;3(1):115-30. http://dx.doi.org/10.1016/j.stemcr.2014.04.020

99. Liu S, Qu Y, Stewart TJ, Howard MJ, Chakrabortty S, Holekamp TF, et al. Embryonic stem cells differentiate into oligodendrocytes and myelinate in culture and after spinal cord transplantation. Proc Natl Acad Sci U S A. 2000;97(11):6126-31. http://dx.doi.org/10.1073/pnas.97.11.6126

100. Shroff $G$. Transplantation of human embryonic stem cells in patients with multiple sclerosis and lyme disease. Am J Case Rep. 2016;17:944. http://dx.doi.org/10.12659/AJCR.899745

101. Takahashi K, Yamanaka S. Induction of pluripotent stem cells from mouse embryonic and adult fibroblast cultures by defined factors. Cell. 2006;126(4):663-76. http://dx.doi.org/10.1016/j. cell.2006.07.024

102. Takahashi K, Tanabe K, Ohnuki M, Narita M, Ichisaka T, Tomoda K, et al. Induction of pluripotent stem cells from adult human fibroblasts by defined factors. Cell. 2007;131(5):861-72. http://dx.doi. org/10.1016/j.cell.2007.11.019

103. Czepiel M, Balasubramaniyan V, Schaafsma W, Stancic M, Mikkers H, Huisman C, et al. Differentiation of induced pluripotent stem cells into functional oligodendrocytes. Glia. 2011;59(6):882-92. http:// dx.doi.org/10.1002/glia.21159

104. Naegele JR, Maisano X, Yang J, Royston S, Ribeiro E. Recent advancements in stem cell and gene therapies for neurological disorders and intractable epilepsy. Neuropharmacology. 2010;58(6): 855-64. http://dx.doi.org/10.1016/j.neuropharm.2010.01.019

105. Laterza C, Merlini A, De Feo D, Ruffini F, Menon R, Onorati M, et al. iPSC-derived neural precursors exert a neuroprotective role in immune-mediated demyelination via the secretion of LIF. Nat Commun. 2013;4:2597. http://dx.doi.org/10.1038/ncomms3597

106. Wang S, Bates J, Li X, Schanz S, Chandler-Militello D, Levine C, et al. Human iPSC-derived oligodendrocyte progenitor cells can myelinate and rescue a mouse model of congenital hypomyelination. Cell Stem Cell. 2013;12(2):252-64. http://dx.doi.org/10.1016/j.stem.2012.12.002

107. Bojnordi MN, Azizi H, Skutella T, Movahedin M, Pourabdolhossein F, Shojaei A, et al. Differentiation of spermatogonia stem cells into functional mature neurons characterized with differential gene expression. Mol Neurobiol. 2017;54(7):5676-5682. http://dx.doi.org/10.1007/s12035-016-0097-7

108. Mizrak S, Chikhovskaya J, Sadri-Ardekani H, Van Daalen S, Korver C, Hovingh S, et al. Embryonic stem cell-like cells derived from adult human testis. Hum Reprod. 2009;25(1):158-67. http://dx.doi. org/10.1093/humrep/dep354

109. Bojnordi MN, Movahedin M, Tiraihi T, Javan M. Alteration in genes expression patterns during in vitro differentiation of mouse spermatogonial cells into neuroepithelial-like cells. Cytotechnology. 2013;65(1):97-104. http://dx.doi.org/10.1007/s10616-012-9465-y

110. Mardanpour P, Guan K, Nolte J, Lee JH, Hasenfuss G, Engel W, et al. Potency of germ cells and its relevance for regenerative medicine. J Anat. 2008;213(1):26-9. http://dx.doi. org/10.1111/j.1469-7580.2008.00930.x

111. Bojnordi MN, Movahedin M, Tiraihi T, Javan M. A simple co-culture system for generation of embryonic stem-like cells from testis. Iran Red Crescent Med J. 2012;14(12):811. http://dx.doi.org/10.5812/ ircmj. 4051

112. Kanatsu-Shinohara M, Shinohara T. The germ of pluripotency. Nat Biotechnol. 2006;24(6):663-4. http://dx.doi.org/10.1038/nbt0606-663

113. Martino G, Pluchino S. The therapeutic potential of neural stem cells. Nat Rev Neurosci. 2006;7(5):395. http://dx.doi.org/10.1038/nrn1908

114. Baker D, Amor S. Mouse models of multiple sclerosis: Lost in translation? Curr Pharm Design. 2015;21(18):2440-52. http://dx.doi.org/10.2174/1381612821666150316122706

115. Chang A, Tourtellotte WW, Rudick R, Trapp BD. Premyelinating oligodendrocytes in chronic lesions of multiple sclerosis. N Engl J Med. 2002;346(3):165-73. http://dx.doi.org/10.1056/NEJMoa010994 
116. Crawford AH, Tripathi RB, Foerster S, McKenzie I, Kougioumtzidou E, Grist M, et al. Pre-existing mature oligodendrocytes do not contribute to remyelination following toxin-induced spinal cord demyelination. Am J Pathol. 2016;186(3):511-16. http://dx.doi.org/10.1016/j.ajpath.2015. 11.005

117. Chang A, Nishiyama A, Peterson J, Prineas J, Trapp BD. NG2-positive oligodendrocyte progenitor cells in adult human brain and multiple sclerosis lesions. J Neurosci. 2000;20(17):6404-12.

118. Nait-Oumesmar B, Picard-Riera N, Kerninon C, Decker L, Seilhean D, Höglinger GU, et al. Activation of the subventricular zone in multiple sclerosis: Evidence for early glial progenitors. Proc Natl Acad Sci U S A. 2007;104(11):4694-9. http://dx.doi.org/10.1073/pnas.0606835104

119. Jessberger S, Toni N, Clemenson GD Jr, Ray J, Gage FH. Directed differentiation of hippocampal stem/ progenitor cells in the adult brain. Nat Neurosci. 2008;11(8):888-93. http://dx.doi.org/10.1038/nn.2148

120. Xing YL, Röth PT, Stratton JAS, Chuang BH, Danne J, Ellis SL, et al. Adult neural precursor cells from the subventricular zone contribute significantly to oligodendrocyte regeneration and remyelination. J Neurosci. 2014;34(42):14128-46. http://dx.doi.org/10.1523/JNEUROSCI.3491-13.2014

121. Zawadzka M, Rivers LE, Fancy SP, Zhao C, Tripathi R, Jamen F, et al. CNS-resident glial progenitor/ stem cells produce Schwann cells as well as oligodendrocytes during repair of CNS demyelination. Cell Stem Cell. 2010;6(6):578-90. http://dx.doi.org/10.1016/j.stem.2010.04.002

122. Nait-Oumesmar B, Decker L, Lachapelle F, Avellana-Adalid V, Bachelin C, Evercooren V, et al. Progenitor cells of the adult mouse subventricular zone proliferate, migrate and differentiate into oligodendrocytes after demyelination. Eur J Neurosci. 1999;11(12):4357-66. http://dx.doi.org/10. 1046/j.1460-9568.1999.00873.x

123. Fancy SP, Zhao C, Franklin RJ. Increased expression of Nkx2. 2 and Olig2 identifies reactive oligodendrocyte progenitor cells responding to demyelination in the adult CNS. Mol Cell Neurosci. 2004;27(3):247-54. http://dx.doi.org/10.1016/j.mcn.2004.06.015

124. Rhodes K, Raivich G, Fawcett J. The injury response of oligodendrocyte precursor cells is induced by platelets, macrophages and inflammation-associated cytokines. Neuroscience. 2006;140(1):87-100. http://dx.doi.org/10.1016/j.neuroscience.2006.01.055

125. Piaton G, Aigrot M-S, Williams A, Moyon S, Tepavcevic V, Moutkine I, et al. Class 3 semaphorins influence oligodendrocyte precursor recruitment and remyelination in adult central nervous system. Brain. 2011;134(4):1156-67. http://dx.doi.org/10.1093/brain/awr022

126. Fancy SP, Chan JR, Baranzini SE, Franklin RJ, Rowitch DH. Myelin regeneration: A recapitulation of development? Ann Rev Neurosci. 2011;34:21-43. http://dx.doi.org/10.1146/ annurev-neuro-061010-113629

127. Syed YA, Baer AS, Lubec G, Hoeger H, Widhalm G, Kotter MR. Inhibition of oligodendrocyte precursor cell differentiation by myelin-associated proteins. Neurosurg Focus. 2008;24(3-4):E5. http:// dx.doi.org/10.3171/FOC/2008/24/3-4/E4

128. Pourabdolhossein F, Mozafari S, Morvan-Dubois G, Mirnajafi-Zadeh J, Lopez-Juarez A, Pierre-Simons J, et al. Nogo receptor inhibition enhances functional recovery following lysolecithin-induced demyelination in mouse optic chiasm. PLoS One. 2014;9(9):e106378. http://dx.doi.org/10.1371/journal. pone. 0106378

129. Lee X, Shao Z, Sheng G, Pepinsky B, Mi S. LINGO-1 regulates oligodendrocyte differentiation by inhibiting ErbB2 translocation and activation in lipid rafts. Mol Cell Neurosci. 2014;60:36-42. http:// dx.doi.org/10.1016/j.mcn.2014.02.006

130. Mi S, Hu B, Hahm K, Luo Y, Hui ESK, Yuan Q, et al. LINGO-1 antagonist promotes spinal cord remyelination and axonal integrity in MOG-induced experimental autoimmune encephalomyelitis. Nat Med. 2007;13(10):1228. http://dx.doi.org/10.1038/nml664

131. Ye F, Chen Y, Hoang T, Montgomery RL, Zhao X-H, Bu H, et al. HDACl and HDAC2 regulate oligodendrocyte differentiation by disrupting the $\beta$-catenin-TCF interaction. Nature Neurosci. 2009;12(7):829-38. http://dx.doi.org/10.1038/nn.2333

132. Kuhlmann T, Miron V, Cuo Q, Wegner C, Antel J, Brück W. Differentiation block of oligodendroglial progenitor cells as a cause for remyelination failure in chronic multiple sclerosis. Brain. 2008;131(7):1749-58. http://dx.doi.org/10.1093/brain/awn096

133. Kotter MR, Stadelmann C, Hartung H-P. Enhancing remyelination in disease-Can we wrap it up? Brain. 2011;134(7):1882-900. http://dx.doi.org/10.1093/brain/awr014 
134. Giulia Mallucci, Luca Peruzzotti-Jametti, Joshua D. Bernstock, Stefano Pluchino. The role of immune cells, glia and neurons in white and gray matter pathology in multiple sclerosis. Prog Neurobiol. Prog Neurobiol. 2015 Apr; 0:1-22

135. Yuan Liu, Botao Tan, Li Wang, Zaiyun Long, Yingyu Li, Weihong Liao, Yamin Wu. Endogenous neural stem cells in central canal of adult rats acquired limited ability to differentiate into neurons following mild spinal cord injury. Int J Clin Exp Pathol. 2015;8(4):3835-3842

136. Palmer TD, Markakis EA, Willhoite AR, Safar F, Gage FH. Fibroblast growth factor-2 activates a latent neurogenic program in neural stem cells from diverse regions of the adult CNS. J Neurosci. 1999;19(19):8487-97.

137. Gould E. How widespread is adult neurogenesis in mammals? Nat Rev Neurosci. 2007;8(6):481. http://dx.doi.org/10.1038/nrn2147

138. Decimo I, Bifari F, Krampera M, Fumagalli G. Neural stem cell niches in health and diseases. Curr Pharmaceut Design. 2012;18(13):1755-83. http://dx.doi.org/10.2174/138161212799859611

139. Morrison SJ, Spradling AC. Stem cells and niches: Mechanisms that promote stem cell maintenance throughout life. Cell. 2008;132(4):598-611. http://dx.doi.org/10.1016/j.cell.2008.01.038

140. Jordan JD, Ma DK, Ming G-L, Song H. Cellular niches for endogenous neural stem cells in the adult brain. CNS Neurol Dis Drug Targets. 2007;6(5):336-41. http://dx.doi.org/10.2174/187152707783220866

141. Alvarez-Buylla A, Lim DA. For the long run: Maintaining germinal niches in the adult brain. Neuron. 2004;41(5):683-6. http://dx.doi.org/10.1016/S0896-6273(04)00111-4

142. Mirzadeh Z, Merkle FT, Soriano-Navarro M, Garcia-Verdugo JM, Alvarez-Buylla A. Neural stem cells confer unique pinwheel architecture to the ventricular surface in neurogenic regions of the adult brain. Cell Stem Cell. 2008;3(3):265-78. http://dx.doi.org/10.1016/j.stem.2008.07.004

143. Spassky N, Merkle FT, Flames N, Tramontin AD, García-Verdugo JM, Alvarez-Buylla A. Adult ependymal cells are postmitotic and are derived from radial glial cells during embryogenesis. J Neurosci. 2005;25(1):10-18. http://dx.doi.org/10.1523/JNEUROSCI.1108-04.2005

144. Doetsch F, Caille I, Lim DA, García-Verdugo JM, Alvarez-Buylla A. Subventricular zone astrocytes are neural stem cells in the adult mammalian brain. Cell. 1999;97(6):703-16. http://dx.doi.org/10.1016/ S0092-8674(00)80783-7

145. Carleton A, Petreanu LT, Lansford R, Alvarez-Buylla A, Lledo P-M. Becoming a new neuron in the adult olfactory bulb. Nat Neurosci. 2003;6(5):507-518. http://dx.doi.org/10.1038/nn1048

146. Codega P, Silva-Vargas V, Paul A, Maldonado-Soto AR, DeLeo AM, Pastrana E, et al. Prospective identification and purification of quiescent adult neural stem cells from their in vivo niche. Neuron. 2014;82(3):545-59. http://dx.doi.org/10.1016/j.neuron.2014.02.039

147. Tepavčević V, Lazarini F, Alfaro-Cervello C, Kerninon C, Yoshikawa K, Garcia-Verdugo JM, et al. Inflammation-induced subventricular zone dysfunction leads to olfactory deficits in a targeted mouse model of multiple sclerosis. J Clin Investig. 2011;121(12):4722. http://dx.doi.org/10.1172/JCI59145

148. Cayre M, Bancila M, Virard I, Borges A, Durbec P. Migrating and myelinating potential of subventricular zone neural progenitor cells in white matter tracts of the adult rodent brain. Mol Cell Neurosci. 2006;31(4):748-58. http://dx.doi.org/10.1016/j.mcn.2006.01.004

149. Picard-Riera N, Nait-Oumesmar B, Evercooren BV. Endogenous adult neural stem cells: Limits and potential to repair the injured central nervous system. J Neurosci Res. 2004;76(2):223-31. http:// dx.doi.org/10.1002/jnr.20040

150. Menn B, Garcia-Verdugo JM, Yaschine C, Gonzalez-Perez O, Rowitch D, Alvarez-Buylla A. Origin of oligodendrocytes in the subventricular zone of the adult brain. J Neurosci. 2006;26(30):7907-18. http://dx.doi.org/10.1523/JNEUROSCI.1299-06.2006

151. Jablonska B, Aguirre A, Raymond M, Szabo G, Kitabatake Y, Sailor KA, et al. Chordin-induced lineage plasticity of adult SVZ neuroblasts after demyelination. Nat Neurosci. 2010;13(5):541-50. http:// dx.doi.org/10.1038/nn.2536

152. Pourabdolhossein F, Gil-Perotín S, Garcia-Belda P, Dauphin A, Mozafari S, Tepavcevic V, et al. Inflammatory demyelination induces ependymal modifications concomitant to activation of adult (SVZ) stem cell proliferation. Glia. 2017;65(5):756-72. http://dx.doi.org/10.1002/glia.23124

153. Ming G-L, Song H. Adult neurogenesis in the mammalian brain: Significant answers and significant questions. Neuron. 2011;70(4):687-702. http://dx.doi.org/10.1016/j.neuron.2011.05.001 
154. Palmer TD, Willhoite AR, Gage FH. Vascular niche for adult hippocampal neurogenesis. J Comp Neurol. 2000;425(4):479-94. http://dx.doi.org/10.1002/1096-9861(20001002)425:4\%3C479:: AID-CNE2\%3E3.0.CO;2-3

155. Bonaguidi MA, Song J, Ming G-L, Song H. A unifying hypothesis on mammalian neural stem cell properties in the adult hippocampus. Curr Opin Neurobiol. 2012;22(5):754-61. http://dx.doi. org/10.1016/j.conb.2012.03.013

156. Dutta R, Chomyk AM, Chang A, Ribaudo MV, Deckard SA, Doud MK, et al. Hippocampal demyelination and memory dysfunction are associated with increased levels of the neuronal microRNA miR-124 and reduced AMPA receptors. Ann Neurol. 2013;73(5):637-45. http://dx.doi.org/10.1002/ ana. 23860

157. Sicotte N, Kern K, Giesser B, Arshanapalli A, Schultz A, Montag M, et al. Regional hippocampal atrophy in multiple sclerosis. Brain. 2008;131(4):1134-41. http://dx.doi.org/10.1093/brain/awn030

158. Giannakopoulou A, Grigoriadis N, Bekiari C, Lourbopoulos A, Dori I, Tsingotjidou A, et al. Acute inflammation alters adult hippocampal neurogenesis in a multiple sclerosis mouse model. J Neurosci Res. 2013;91(7):890-900. http://dx.doi.org/10.1002/jnr.23226

159. Russo I, Barlati S, Bosetti F. Effects of neuroinflammation on the regenerative capacity of brain stem cells. J Neurochem. 2011;116(6):947-56. http://dx.doi.org/10.1111/j.1471-4159.2010.07168.x

160. Huehnchen P, Prozorovski T, Klaissle P, Lesemann A, Ingwersen J, Wolf SA, Kupsch A, Aktas O, Steiner B. Modulation of adult hippocampal neurogenesis during myelin-directed autoimmune neuroinflammation. Glia. 2011 Jan;59(1):132-42.

161. Geurts JJ, Bö L, Roosendaal SD, Hazes T, Daniëls R, Barkhof F, et al. Extensive hippocampal demyelination in multiple sclerosis. J Neuropathol Exp Neurol. 2007;66(9):819-27. http://dx.doi.org/10.1097/ nen.0b013e3181461f54

162. Horner PJ, Power AE, Kempermann G, Kuhn HG, Palmer TD, Winkler J, et al. Proliferation and differentiation of progenitor cells throughout the intact adult rat spinal cord. J Neurosci. 2000;20(6):2218-28.

163. Kehl LJ, Fairbanks CA, Laughlin TM, Wilcox GL. Neurogenesis in postnatal rat spinal cord: A study in primary culture. Sci. 1997;276(5312):586-9. http://dx.doi.org/10.1126/science.276.5312.586

164. Barnabé-Heider F, Göritz C, Sabelström H, Takebayashi H, Pfrieger FW, Meletis K, et al. Origin of new glial cells in intact and injured adult spinal cord. Cell Stem Cell. 2010;7(4):470-82. http://dx.doi. org/10.1016/j.stem.2010.07.014

165. Hamilton L, Truong M, Bednarczyk M, Aumont A, Fernandes K. Cellular organization of the central canal ependymal zone, a niche of latent neural stem cells in the adult mammalian spinal cord. Neuroscience. 2009;164(3):1044-56. http://dx.doi.org/10.1016/j.neuroscience.2009.09.006

166. Sabelström H, Stenudd M, Réu P, Dias DO, Elfineh M, Zdunek S, et al. Resident neural stem cells restrict tissue damage and neuronal loss after spinal cord injury in mice. Science. 2013;342(6158):637-40. http://dx.doi.org/10.1126/science.1242576

167. Laywell ED, Rakic P, Kukekov VG, Holland EC, Steindler DA. Identification of a multipotent astrocytic stem cell in the immature and adult mouse brain. Proc Natl Acad Sci. 2000;97(25):13883-8. http://dx.doi.org/10.1073/pnas.250471697

168. Migaud M, Batailler M, Segura S, Duittoz A, Franceschini I, Pillon D. Emerging new sites for adult neurogenesis in the mammalian brain: A comparative study between the hypothalamus and the classical neurogenic zones. Eur J Neurosci. 2010;32(12):2042-52. http://dx.doi. org/10.1111/j.1460-9568.2010.07521.x

169. Kokoeva MV, Yin H, Flier JS. Evidence for constitutive neural cell proliferation in the adult murine hypothalamus. J Compar Neurol. 2007;505(2):209-20. http://dx.doi.org/10.1002/cne.21492

170. Bennett L, Yang M, Enikolopov G, Iacovitti L. Circumventricular organs: A novel site of neural stem cells in the adult brain. Mol Cell Neurosci. 2009;41(3):337-47. http://dx.doi.org/10.1016/j. mcn.2009.04.007

171. Mozafari S, Javan M, Sherafat MA, Mirnajafi-Zadeh J, Heibatollahi M, Pour-Beiranvand S, et al. Analysis of structural and molecular events associated with adult rat optic chiasm and nerves demyelination and remyelination; possible role for 3rd ventricle proliferating cells. Neuromol Med. 2011;13(2): 138-50. http://dx.doi.org/10.1007/s12017-011-8143-0 
172. Xu Y, Tamamaki N, Noda T, Kimura K, Itokazu Y, Matsumoto N, et al. Neurogenesis in the ependymal layer of the adult rat 3rd ventricle. Exp Neurol. 2005;192(2):251-64. http://dx.doi.org/10.1016/j. expneurol.2004.12.021

173. Decimo I, Bifari F, Rodriguez FJ, Malpeli G, Dolci S, Lavarini V, et al. Nestin-and doublecortin-positive cells reside in adult spinal cord meninges and participate in injury-induced parenchymal reaction. Stem Cells. 2011;29(12):2062-76. http://dx.doi.org/10.1002/stem.766

174. Matsas R, Lavdas A, Papastefanaki F, Thomaidou D. Schwann cell transplantation for CNS repair. Curr Med Chem. 2008;15(2):151-60. http://dx.doi.org/10.2174/092986708783330593

175. Violetta Zujovic, Cédric Doucerain, Antoine Hidalgo, Corinne Bachelin, François Lachapelle, Robert Weissert, Christine Stadelmann, Chris Linington, Anne Baron-Van Evercooren". Exogenous Schwann Cells Migrate, Remyelinate and Promote Clinical Recovery in Experimental Auto-Immune Encephalomyelitis. PLoS One. 2012;7(9):e42667. 1-8

176. Duncan I, Aguayo A, Bunge R, Wood P. Transplantation of rat Schwann cells grown in tissue culture into the mouse spinal cord. J Neurol Sci. 1981;49(2):241-52. http://dx.doi. org/10.1016/0022-510X(81)90082-4

177. Honmou O, Felts PA, Waxman SG, Kocsis JD. Restoration of normal conduction properties in demyelinated spinal cord axons in the adult rat by transplantation of exogenous Schwann cells. J Neurosci. 1996;16(10):3199-208.

178. Oudega M, Xu X-M. Schwann cell transplantation for repair of the adult spinal cord. J Neurotrauma. 2006;23(3-4):453-67. http://dx.doi.org/10.1089/neu.2006.23.453

179. Lakatos A, Barnett SC, Franklin RJ. Olfactory ensheathing cells induce less host astrocyte response and chondroitin sulphate proteoglycan expression than Schwann cells following transplantation into adult CNS white matter. Exp Neurol. 2003;184(1):237-46. http://dx.doi.org/10.1016/ S0014-4886(03)00270-X

180. Yamauchi J, Miyamoto Y, Tanoue A, Shooter EM, Chan JR. Ras activation of a Racl exchange factor, Tiaml, mediates neurotrophin-3-induced Schwann cell migration. Proc Natl Acad Sci U S A. 2005;102(41):14889-94. http://dx.doi.org/10.1073/pnas.0507125102

181. Girard C, Bemelmans A-P, Dufour N, Mallet J, Bachelin C, Nait-Oumesmar B, et al. Grafts of brainderived neurotrophic factor and neurotrophin 3-transduced primate Schwann cells lead to functional recovery of the demyelinated mouse spinal cord. J Neurosci. 2005;25(35):7924-33. http://dx.doi. org/10.1523/JNEUROSCI.4890-04.2005

182. Afshari FT, Kwok JC, White L, Fawcett JW. Schwann cell migration is integrin-dependent and inhibited by astrocyte-produced aggrecan. Glia. 2010;58(7):857-69. http://dx.doi.org/10.1002/glia.20970

183. Vincent AJ, West AK, Chuah MI. Morphological and functional plasticity of olfactory ensheathing cells. J Neurocytol. 2005;34(1-2):65-80. http://dx.doi.org/10.1007/s11068-005-5048-6

184. Forni PE, Taylor-Burds C, Melvin VS, Williams T, Wray S. Neural crest and ectodermal cells intermix in the nasal placode to give rise to GnRH-1 neurons, sensory neurons, and olfactory ensheathing cells. J Neurosci. 2011;31(18):6915-27. http://dx.doi.org/10.1523/JNEUROSCI.6087-10.2011

185. Deng C, Gorrie C, Hayward I, Elston B, Venn M, Mackay-Sim A, et al. Survival and migration of human and rat olfactory ensheathing cells in intact and injured spinal cord. J Neurosci Res. 2006;83(7):1201-12. http://dx.doi.org/10.1002/jnr.20817

186. Toft A, Tomé M, Lindsay SL, Barnett SC, Riddell JS. Transplant-mediated repair properties of rat olfactory mucosal OM-I and OM-II sphere-forming cells. J Neurosci Res. 2012;90(3):619-31. http:// dx.doi.org/10.1002/jnr.22789

187. Andrews MR, Stelzner DJ. Evaluation of olfactory ensheathing and Schwann cells after implantation into a dorsal injury of adult rat spinal cord. J Neurotrauma. 2007;24(11):1773-92. http://dx.doi. org/10.1089/neu.2007.0353

188. Lankford KL, Sasaki M, Radtke C, Kocsis JD. Olfactory ensheathing cells exhibit unique migratory, phagocytic, and myelinating properties in the X-irradiated spinal cord not shared by Schwann cells. Glia. 2008;56(15):1664-78. http://dx.doi.org/10.1002/glia.20718

189. Woodhoo A, Sahni V, Gilson J, Setzu A, Franklin R, Blakemore W, et al. Schwann cell precursors: A favourable cell for myelin repair in the Central Nervous System. Brain. 2007;130(8):2175-85. http:// dx.doi.org/10.1093/brain/awm125 
190. Aquino JB, Hjerling-Leffler J, Koltzenburg M, Edlund T, Villar MJ, Ernfors P. In vitro and in vivo differentiation of boundary cap neural crest stem cells into mature Schwann cells. Exp Neurol. 2006;198(2):438-49. http://dx.doi.org/10.1016/j.expneurol.2005.12.015

191. Zujovic V, Thibaud J, Bachelin C, Vidal M, Coulpier F, Charnay P, et al. Boundary cap cells are highly competitive for CNS remyelination: Fast migration and efficient differentiation in PNS and CNS myelin-forming cells. Stem Cells. 2010;28(3):470-9. http://dx.doi.org/10.1002/stem.290

192. Zujovic V, Thibaud J, Bachelin C, Vidal M, Deboux C, Coulpier F, et al. Boundary cap cells are peripheral nervous system stem cells that can be redirected into central nervous system lineages. Proc Natl Acad Sci U S A. 2011;108(26):10714-19. http://dx.doi.org/10.1073/pnas.1018687108

193. Lu J, Ashwell K. Olfactory ensheathing cells: Their potential use for repairing the injured spinal cord. Spine. 2002;27(8):887-92. http://dx.doi.org/10.1097/00007632-200204150-00021

194. Markakis EA, Sasaki M, Lankford KL, Kocsis JD. Convergence of cells from the progenitor fraction of adult olfactory bulb tissue to remyelinating glia in demyelinating spinal cord lesions. PLoS One. 2009;4(9):e7260. http://dx.doi.org/10.1371/journal.pone.0007260

195. Craig CG, Tropepe V, Morshead CM, Reynolds BA, Weiss S, Van der Kooy D. In vivo growth factor expansion of endogenous subependymal neural precursor cell populations in the adult mouse brain. J Neurosci. 1996;16(8):2649-58.

196. Shimazaki T, Shingo T, Weiss S. The ciliary neurotrophic factor/leukemia inhibitory factor/gp130 receptor complex operates in the maintenance of mammalian forebrain neural stem cells. J Neurosci. 2001;21(19):7642-53.

197. Ramírez-Castillejo C, Sánchez-Sánchez F, Andreu-Agulló C, Ferrón SR, Aroca-Aguilar JD, Sánchez P, et al. Pigment epithelium-derived factor is a niche signal for neural stem cell renewal. Nat Neurosci. 2006;9(3):331. http://dx.doi.org/10.1038/nn1657

198. Pencea V, Bingaman KD, Wiegand SJ, Luskin MB. Infusion of brain-derived neurotrophic factor into the lateral ventricle of the adult rat leads to new neurons in the parenchyma of the striatum, septum, thalamus, and hypothalamus. J Neurosci. 2001;21(17):6706-17.

199. Teramoto T, Qiu J, Plumier J-C, Moskowitz MA. EGF amplifies the replacement of parvalbuminexpressing striatal interneurons after ischemia. J Clin Investig. 2003;111(8):1125. http://dx.doi. org/10.1172/JCI200317170

200. Dehghan S, Javan M, Pourabdolhossein F, Mirnajafi-Zadeh J, Baharvand H. Basic fibroblast growth factor potentiates myelin repair following induction of experimental demyelination in adult mouse optic chiasm and nerves. J Mol Neurosci. 2012;48(1):77-85. http://dx.doi.org/10.1007/ s12031-012-9777-6

201. Pazhoohan S, Satarian L, Asghari A-A, Salimi M, Kiani S, Mani A-R, et al. Valproic acid attenuates disease symptoms and increases endogenous myelin repair by recruiting neural stem cells and oligodendrocyte progenitors in experimental autoimmune encephalomyelitis. Neurodegener Dis. 2014;13(1):45-52.

202. Mohajeri M, Sadeghizadeh M, Najafi F, Javan M. Polymerized nano-curcumin attenuates neurological symptoms in EAE model of multiple sclerosis through down regulation of inflammatory and oxidative processes and enhancing neuroprotection and myelin repair. Neuropharmacology. 2015;99:156-67. http://dx.doi.org/10.1016/j.neuropharm.2015.07.013

203. Hui-Dong W, Dunnavant FD, Jarman T, Deutch AY. Effects of antipsychotic drugs on neurogenesis in the forebrain of the adult rat. Neuropsychopharmacology. 2004;29(7):1230. http://dx.doi. org/10.1038/sj.npp.1300449

204. Petratos S, Ozturk E, Azari MF, Kenny R, Young Lee J, Magee KA, et al. Limiting multiple sclerosis related axonopathy by blocking Nogo receptor and CRMP-2 phosphorylation. Brain. 2012;135(6):1794-818. http://dx.doi.org/10.1093/brain/aws100

205. Jepson S, Vought B, Gross CH, Gan L, Austen D, Frantz JD, et al. LINGO-1, a transmembrane signaling protein, inhibits oligodendrocyte differentiation and myelination through intercellular self-interactions. J Biol Chem. 2012;287(26):22184-95. http://dx.doi.org/10.1074/jbc.M112. 366179

206. Yang Y, Liu Y, Wei P, Peng H, Winger R, Hussain RZ, et al. Silencing Nogo-A promotes functional recovery in demyelinating disease. Ann Neurol. 2010;67(4):498-507. http://dx.doi.org/10.1002/ana.21935 


\section{Stem Cell Therapy for Multiple Sclerosis}

207. Yu P, Huang L, Zou J, Yu Z, Wang Y, Wang X, et al. Immunization with recombinant Nogo-66 receptor $(\mathrm{NgR})$ promotes axonal regeneration and recovery of function after spinal cord injury in rats. Neurobiol Dis. 2008;32(3):535-42. http://dx.doi.org/10.1016/j.nbd.2008.09.012

208. Khezri S, Javan M, Goudarzvand M, Semnanian S, Baharvand H. Dibutyryl cyclic AMP inhibits the progression of experimental autoimmune encephalomyelitis and potentiates recruitment of endogenous neural stem cells. J Mol Neurosci. 2013;51(2):298-306. http://dx.doi.org/10.1007/ s12031-013-9959-x 